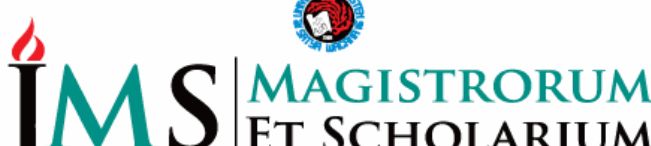 \\ - JURNAL PENGABDIAN MASYARAKAT
}

P-ISSN: 2722-9270 ejournal.uksw.edu/jms

\section{Pendampingan Santri untuk Penurunan Tingkat Pelanggaran Lalu Lintas}

\author{
Ali Azhar \\ KMS Novyar Sariawan Fikri \\ Mulono Apriyanto* \\ Fakultas Hukum, Universitas Islam Indragiri
}

\section{Article history: \\ Received 26-11-2020 \\ Revised 28-11-2020 \\ Accepted 20-12-2020}

A R T I C L E I N F O

Key words:

Kepolisaian resort Indragiri Hiri 1, Sabilal Muthadin 2, lalu lintas 3

\begin{abstract}
A B S T R A C T
Traffic violations by motor vehicles from 2018-2019 have increased quite rapidly. As an educational institution, the legal science study program cooperates with the traffic department of the Indragiri Hilir resort police to conduct socialization and assistance to students of the Sabilal Muthadin Islamic boarding school as an effort to tackle traffic violations. One of them is by taking precautionary measures to prevent police traffic violations committed by motorized vehicles, providing education about traffic and reminding the public about the importance of respecting traffic signs and installing traffic-related banners. Traffic violations among students in the Kepolisian area of the Indragiri Hiri resort can be brought down after mentoring.
\end{abstract}

\begin{abstract}
A B S T R A K
Pelanggaran lalu lintas oleh kendaraan bermotor dari tahun 20182019 telah meningkat cukup pesat. Sebagai lembaga pendidikan program studi ilmu hukum berkerjasama kantor polisi resort Indragiri Hilir bagian lalu lintas melakuan sosialisasi dan pendampingan kepada santri pondok pesantren Sabilal Muthadin sebagai upaya dalam menanggulangi pelanggaran lalu lintas. Salah satunya dengan langkah-langkah pencegahan pencegahan pelanggaran lalu lintas polisi yang dilakukan oleh kendaraan bermotor, melakukan penyuluhan tentang lalu lintas dan mengingatkan masyarakat tentang pentingnya menghormati rambu-rambu lalu lintas dan memasang spanduk yang berkaitan dengan lalu lintas. Pelanggaran lalu lintas dikalangan pelajar dalam wilayah Kepolisaian resort Indragiri Hiri dapat diturunkan setelah pendampingan.
\end{abstract}

\footnotetext{
* Corresponding author: mulonoapriyanto71@ gmail.com
} 


\section{PENDAHULUAN}

Jumlah kepemilikan sepeda motor setiap tahun meningkat, ditambah lagi akses jam pelayanan transportasi umum yang dibatasi menjadi salah satu alasan meningkatnya jumlah kendaraan bermotor. Pesatnya pertumbuhan kepemilikan kendaraan bermotor di Indonesia dalam tahun-tahun terakhir, dikombinasikan pula dengan penduduk dengan usia yang relatif muda dan beragamnya jenis kendaraan telah mengakibatkan masalah keselamatan jalan yang kian memburuk.

Tingginya tingkat kecelakaan pada sepeda motor yang banyak memakan korban jiwa membuat pemerintah dalam hal ini mengeluarkan Undang-Undang (UU) No. 22 Tahun 2009 tentang Lalu Lintas dan Angkutan Jalan yang pada awalnya merupakan UU No. 14 Tahun 1992 tentang Lalu Lintas dan Angkutan Jalan. Pemerintah merevisi UU tersebut supaya terbentuk undang-undang yang lebih sempurna, efektif dan aplikatif dalam hal ikhwal penyelenggaraan lalu lintas dan angkutan jalan sesuai harapan masyarakat, sejalan dengan kondisi dan kebutuhan penyelenggaraan lalu lintas dan angkutan jalan saat ini. Lahirnya UU No. 22 Tahun 2009 bertujuan untuk membina dan menyelenggarakan Lalu Lintas dan Angkutan Jalan yang aman, selamat, tertib, dan lancar. Untuk menekan angka kecelakaan lalu lintas yang dirasakan sangat tinggi, upaya ke depan diarahkan pada penanggulangan secara komprehensif yang mencakup upaya pembinaan, pencegahan, pengaturan, dan penegakan hukum. Upaya pembinaan tersebut dilakukan melalui peningkatan intensitas pendidikan berlalu lintas dan penyuluhan hukum serta pembinaan sumber daya manusia. Salah satunya adalah dengan memberikan penyuluhan atau sosialisasi UU No. 22 Tahun 2009 terhadap pengguna jalan, khususnya kepada para pengendara sepeda motor.

Transportasi jalan diselenggarakan dengan tujuan mewujudkan lalu lintas dan angkutan jalan dengan selamat, aman, cepat, lancar, tertib, dan teratur, nyaman, efisien, mampu memadukan moda transportasi lainnya, menjangkau seluruh pelosok wilayah daratan, untuk menunjang pemerataan, penggerak dan penunjang pembangunan nasional dengan biaya yang terjangkau oleh daya beli masyarakat (Azhar \& Satriawan, 2020). Lalu lintas dan angkutan jalan mempunyai peran strategis dalam mendukung pembangunan dan integrasi nasional sebagai bagian dari upaya memajukan kesejahteraan umum.

Sistem transportasi nasional harus dikembangkan potensi dan perannya dalam mewujudkan keamanan, keselamatan, ketertiban, dan kelancaran berlalu lintas. Hal ini dimaksudkan untuk mendukung pembangunan ekonomi dan pengembangan wilayah, dengan perkembangan ilmu pengetahuan dan teknologi, otonomi daerah, serta akuntabilitas (Fikri \& Azhar, 2020). Dalam upaya pembaharuan hukum dan pemantapan peranan badan-badan penegak hukum negara yang terarah sangat dibutuhkan untuk dapat mendukung pembangunan nasional serta kesadaran hukum, khususnya di bidang transportasi yang berkembang dalam masyarakat Indonesia (Azhar \& Arfiani, 2020). Undang-Undang Nomor 22 Tahun 2009 Tentang Lalu Lintas dan Angkutan Jalan, bahwa kendaraan dan orang yang bergerak diruang lalu lintas jalan. Ruang lalu lintas adalah prasarana yang diperuntukkan bagi gerak pindah kendaraan, orang, dan atau barang yang berupa jalan serta fasilitas pendukung.

Kesadaran hukum juga diperlukan sebagai sikap yang perlu ditanamkan kepada seluruh warga negara sebagai rasa tanggung jawab terhadap lancarnya roda 
pembangunan. Untuk mewujudkan masyarakat yang sadar hukum perlu adanya usaha agar hukum tersebut diketahui, dimengerti, ditaati dan dihargai. Usaha tersebut adalah hal yang mutlak untuk dilaksanakan mengingat adanya kecenderungan perilaku melawan atau melanggar hukum yang semakin meningkat seiring dengan perkembangan ilmu pengetahuan dan teknologi.

Berbagai upaya pemerintah dalam meningkatkan pengetahuan hukum masyarakat seperti melakukan sosialisasi, sehubungan dengan hal tersebut, lembaga pendidikan formal (sekolah) mempunyai peranan yang sangat penting dalam memberikan pemahaman kepada warga masyarakat agar mempunyai sikap hormat dan mematuhi kaidah-kaidah hukum yang berlaku. Berdasarkan uraian di atas bahwa pengetahuan hukum masyarakat terhadap peraturan lalu lintas merupakan salah satu faktor penting dalam menyelenggarakan peraturan lalu lintas, untuk itu kesadaran hukum perlu ditanamkan kepada seluruh masyarakat selaku pengguna jalan raya, sebagai rasa tanggung jawab terhadap lancarnya roda pembangunan. Untuk mewujudkan masyarakat yang sadar hukum perlu adanya usaha agar hukum tersebut diketahui, dimengerti, ditaati, dan dihargai. Apabila sikap sikap tersebut sudah tertanam dalam diri setiap masyarakat maka rasa memiliki terhadap hukum akan semakin kuat dan menjiwai sikap-sikap dan perilaku yang sadar akan hukum.

Pemerintah mempunyai tujuan untuk mewujudkan lalu lintas dan angkutan jalan yang selamat, aman, cepat, lancar, tertib dam teratur, nyaman dan efisien melalui manajemen lalu lintas dan rekayasa lalu lintas (Muharlisiani et al., 2019). Tata cara berlalu lintas di jalan diatur dengan peraturan perundangan menyangkut arah lalu lintas, prioritas menggunakan jalan, lajur lalu lintas, jalur lalu lintas dan pengendalian arus dipersimpangan (Apriyanto, Fikri, Siregar, Jamri, \& Azhar, 2020). Untuk mengatur hal tersebut maka diperlukan rambu-rambu lalu lintas untuk membantu arus lalu lintas dijalan tersebut, rambu-rambu tersebut terdiri dari 4 golongan yaitu rambu peringatan, rambu larangan, rambu perintah, rambu petunjuk.

Transportasi nasional mempunyai potensi dikembangkan system keamanan, keselamatan, ketertiban, dan kelancaran berlalu lintas. Sistem tersebut dapat mendukung kelancaran berlalu lintas serta angkutan jalan raya dalam rangka pembangunan ekonomi dan pengembangan wilayah. Dengan memanfaatkan perkembangan ilmu pengetahuan dan teknologi (Badrunsyah \& Cahyono, 2019), upaya pembaharuan hukum dan pemantapan peranan badan-badan penegak hukum negara yang terarah dan dibutuhkan untuk dapat mendukung pembangunan nasional serta kesadaran hukum khususnya dibidang transportasi yang berkembang dalam masyarakat Indonesia.

Permasalahan yang kompleks dalam hal ini banyak para warga masyarakat yang melanggar aturan tata tertib lalu lintas seperti mengendarai motor tanpa Surat Ijin Mengemudi (SIM), boncengan tidak memakai helm, dan sebagainya. Hal ini diakibatkan karena kurangnya kesadaran hukum masyarakat dalam berlalu lintas. Pendampingan ini bertujuan untuk meningkatkan kesadaran masyarakat sehingga pelanggaran lalu lintas akan berkurang. 


\section{METODE PELAKSANAAN}

Penyuluhan ini dilakukan di Madrasah Aliyah pondok pesantren Sabilal Muthadin, karena di wilayah hukum polisi resort Indragiri Hilir tersebut jumlah pelanggaran lalu lintas oleh kendaraan bermotor masih meningkat dari tahun sebelumnya. Pendampingan ini dapat digolongkan dalam jenis yuridis sosiologis yang artinya meninjau keadaan permasalahan yang ada di lapangan dikaitkan dengan aspek hukum yang berlaku dan yang mengatur permasalahan tersebut.

\section{HASIL DAN PEMBAHASAN}

\section{Peran Akademisi dalam langkah preventif}

Langkah preventif, adalah langkah pencegahan awal dari pihak Kepolisian terhadap pelanggaran lalu lintas yang dilakukan oleh kendaraan bermotor. 18 Usaha pencegahan yang dilakukan oleh Polisi Resort Indragiri Hilir adalah:

a) Melakukan Penyuluhan bersama Perguruan Tinggi

Sebagaimana yang diatur didalam Pasal 6 ayat 1 Undang-Undang Lalu Lintas dan Angkutan Jalan yaitu: pembinaan lalu lintas dan angkutan jalan yang dilakukan oleh instansi pembina yang meliputi didalam butir d yang menerangkan bahwa: pemberian bimbingan, pelatihan, sertifikasi, pemberian izin, dan bantuan teknis kepada pemerintah provinsi dan pemerintah kabupaten atau kota. Langkah awal yang menjadi sasaran dalam melakukan penyuluhan ini adalah para pelajar, untuk mencegah terjadinya pelanggaran lalu lintas oleh kendaraan bermotor yang umumnya banyak dilakukan oleh para pelajar. Penyuluhan yang dilakukan seperti sosialisasi dan penerangan tentang ramburambu lalu lintas ke sekolah-sekolah dengan maksud memberikan penerangan tentang pentingnya mematuhi rambu-rambu lalu lintas, dan menerangkan apa risiko yang akan terjadi jika melanggar rambu-rambu lalu lintas. Data yang dikumpulkan, pelanggaran lalu lintas oleh kendaraan bermotor paling banyak dilakukan oleh para pelajar dan mahasiswa. Adapun penyuluhan yang dilakukan oleh Satlantas Indragiri Hilir dapat dilihat dalam tabel berikut:

Tabel 1. Data Penyuluhan Pentingnya Keselamatan Berlalu Lintas Pada Tahun 2018-2020

\begin{tabular}{ccccc}
\hline No & Tahun & Jumlah Sekolah & Jumlah Siswa & Jumlah \\
\hline 1 & 2018 & 4 & 100 & 104 \\
2 & 2019 & 7 & 250 & 257 \\
\hline
\end{tabular}

Dari tabel 1 dapat dilihat bahwa tindakan preventif yang dilakukan oleh Satlantas Indragiri Hilir berupa penyuluhan sudah dilakukan, penyuluhan tersebut dilakukan ke sekolah-sekolah maupun ke mahasiswa. Kegiatan penyuluhan dalam ruang kelas tersaji pada gambar 1 . 


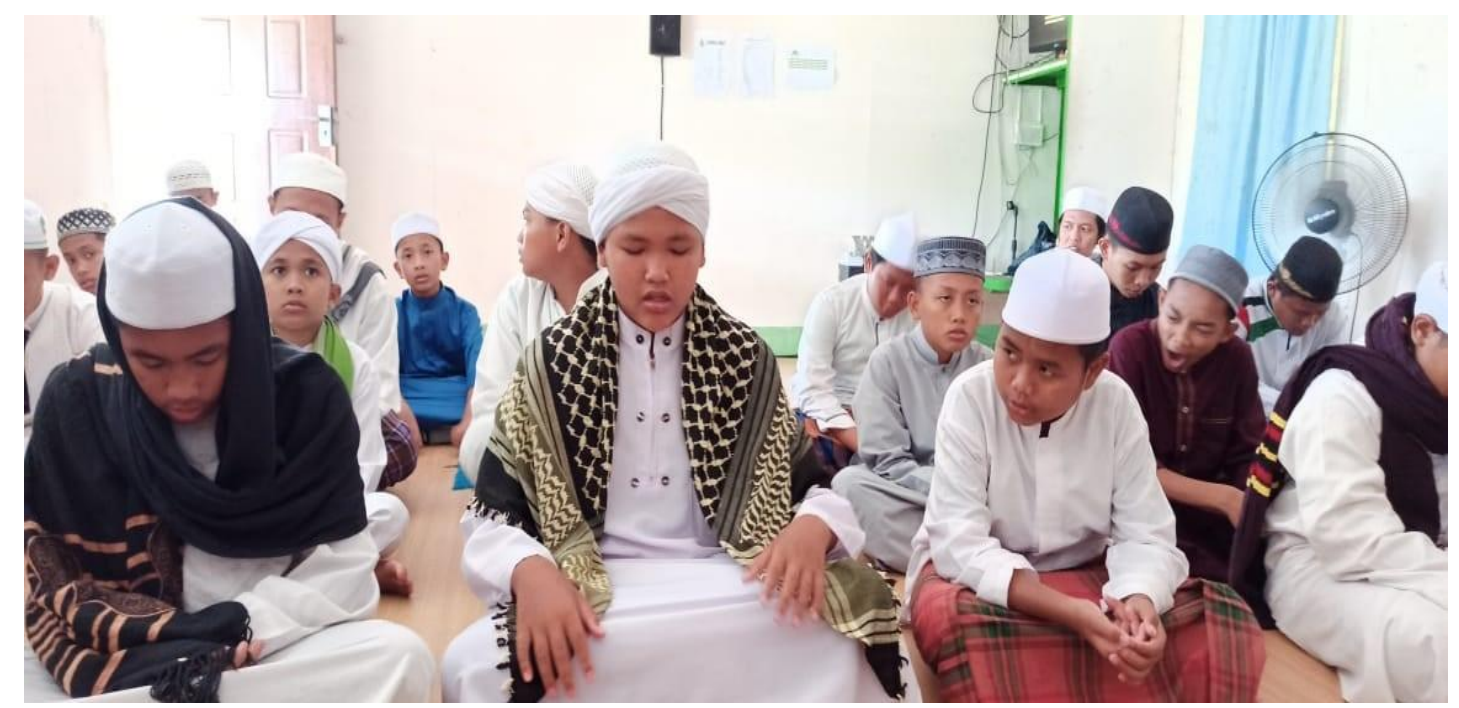

Gambar 1. Foto Peserta Penyuluhan

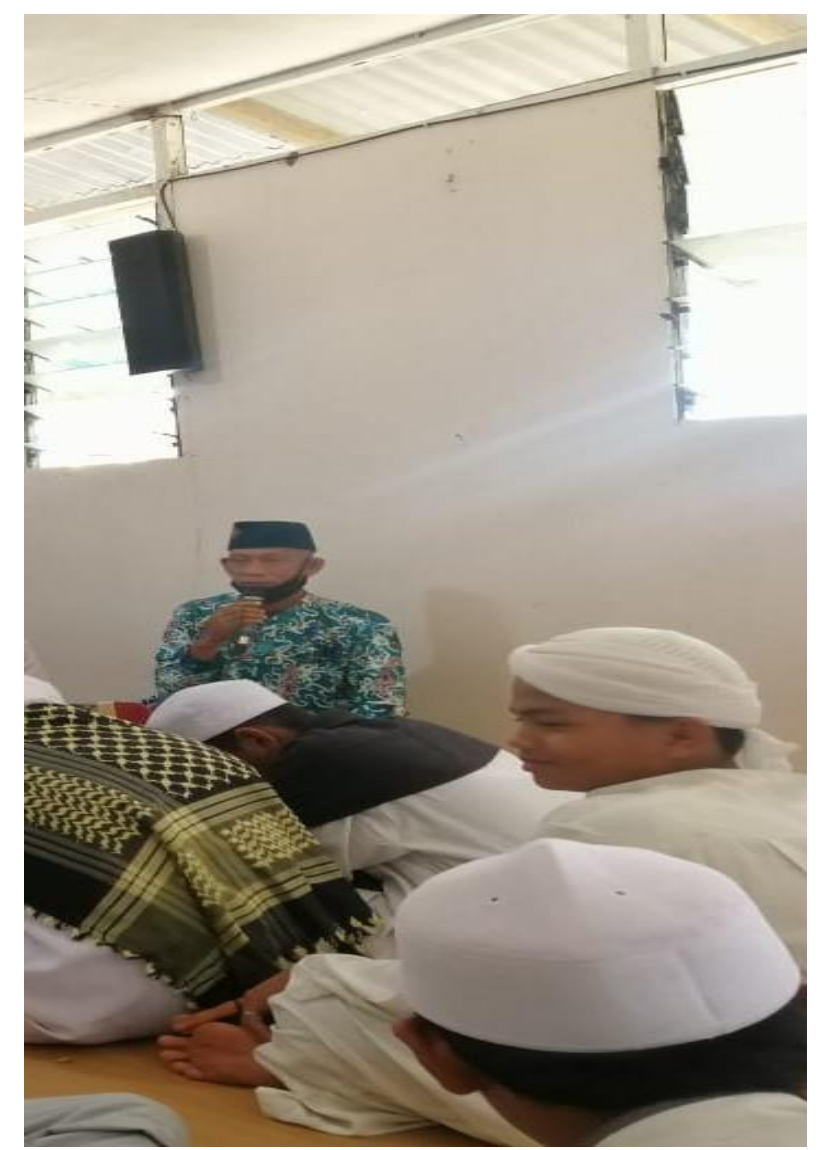

Gambar 2. Pemateri Penyuluhan dari dosen Fakultas Hukum Universitas Islam Indragiri 
b) Evaluasi Kegiatan Penyuluhan

Guna mengevaluasi sejauh mana peserta dapat menerima dan memahami perundang-undangan lalu lintas, dilakukan pre-test dana post-test. Hasil pre-test dan post-test peserta mengenai peningkatan pemahaman Undang-undang Lalu Lintas serta peningkatan pengetahuan siswa pondok pesantren Sabilal Muhtadin sebanyak 40 orang dalam berkendara dan mematuhi aturan lalu lintas disajikan pada Tabel 2. Skala yang digunakan adalah 1 hingga 5. Poin 1 menunjukkan sangat rendah, poin 2 adalah rendah, poin 3 adalah bisa melaksanakan, poin 4 mampu memahami dan melaksanakan, dan poin 5 mampu menerapkan aturan berkendara di jalan raya sesuai Undang-Undang Lalu Lintas.

Tabel 2. Peningkatan Pengetahuan dan Pemahaman Peserta Terhadap Undang-undang Lalu Lintas.

\begin{tabular}{lcccc}
\hline \multicolumn{1}{c}{ Indikator } & \multicolumn{2}{c}{ Pre-test } & \multicolumn{2}{c}{ Post test } \\
& Peserta & Rata-rata & Peserta & Rata-rata \\
\hline $\begin{array}{l}\text { Pengetahuan tentang jenis } \\
\text { kendaraan bermotor }\end{array}$ & 40 & 2 & 40 & 4 \\
$\begin{array}{l}\text { Pengetahuan tentang peralatan } \\
\text { keamanan berkendaraan bermotor }\end{array}$ & 40 & 1 & 40 & 4 \\
$\begin{array}{l}\text { Pengetahuan tentang jenis Surat } \\
\text { Ijin Mengemudi (SIM) }\end{array}$ & 40 & 2 & 40 & 4 \\
$\begin{array}{l}\text { Peningkatan pengetahuan tentang } \\
\text { rambu-rambu lalu lintas }\end{array}$ & 40 & 1 & 40 & 4 \\
\hline
\end{tabular}

Hasil evaluasi menunjukkan peningkatan pemahaman peserta terjadi peningkatan. Hasil pre-test menunjukkan bahwa pengetahuan tentang jenis kendaraan bermotor rata-rata poin 2 berarti rendah. Pengetahuan tentang peralatan keamanan berkendaraan bermotor rata-rata poin 1 berarti sangat rendah. Pengetahuan tentang jenis surat ijin mengemudi rata-rata poin 2 berarti rendah. Peningkatan pengetahuan tentang rambu rambu lalu lintas rata-rata poin 1 berarti sangat rendah. Hasil pre-test tersebut secara umum 40 peserta dalam kondisi belum memahami dan pengetahuan tentang hal tersebut masih sangat rendah atau belum mengetahui. Setelah penyuluhan menunjukkan peningkatan pengetahuan. Hasil post test 40 orang peserta menunjukan pengetahuan tentang jenis kendaraan bermotor mempunyai nilai rata-rata poin 4 berarti mampu memahami dan melaksanakan aturan perundang-undangan. Pengetahuan tentang peralatan keamanan berkendaraan bermotor rata-rata poin 4 berarti mampu memahami dan melaksanakan aturan perundang-undangan. Pengetahuan tentang jenis surat ijin mengemudi rata-rata poin 4 berarti mampu memahami dan melaksanakan aturan perundang-undangan. Peningkatan pengetahuan tentang rambu rambu lalu lintas rata-rata poin 4 berarti mampu memahami dan melaksanakan aturan perundangundangan.

Berdasarkan tabel 2 menunjukan bahwa sebelum penyuluhan secara umum peserta tidak memahami perundang-undangan lalu lintas. Baik secara peralatan kendaraan bermotor yang berfungsi sebagai sarana keamanan. Selanjutnya setelah dilakukan post-test terlihat peningkatan pemahaman terhadap Undang-undang Lalu Lintas dan Angkutan Jalan. 


\section{Peranan Bidang Represif}

Lalu lintas merupakan suatu pergerakan kendaraan dan manusia di jalan dari suatu tempat ke tempat yang lain dengan menggunakan alat gerak. Dalam penelitian ini akan dibahas tentang pemahaman hukum berlalu lintas masyarakat dengan berpatokan pada indikator-indikator berlalu lintas : (1) pemahaman mengenai ramburambu lalu lintas, (2) perlengkapan saat berkendaraan (3) pemahaman mengenai sanksi hukum terhadap pelanggaran berlalu lintas. Indikator-indikator tersebut dapat menunjukkan tingkat pengetahuan masyarakat mengenai aturan-aturan dalam berlalu lintas.

Upaya represif merupakan suatu tindakan yang dilakukan oleh aparat penegak hukum sesudah terjadinya kejahatan atau pelanggaran. Seiring dengan penanggulangan pelanggaran lalu lintas oleh kendaraan bermotor di wilayah hukum Polisi Resort Indragiri Hilir yang bersifat preventif, maka perlu dilaksanakan upaya penanggulangan yang bersifat represif.

\section{Peranan Bidang Represif}

Undang-Undang Nomor 22 Tahun 2009 di dalam Pasal 265 ayat 3 tentang Lalu Lintas dan Aturan Jalan yaitu: untuk melaksanakan suatu tindakan berupa pemeriksaan kendaraan bermotor, petugas kepolisian Republik Indonesia berwenang untuk melakukan tindakan lain berupa menghentikan kendaraan bermotor, meminta keterangan kepada pengemudi dan melakukan tindakan lain menurut hukum secara bertanggungjawab. Meski Undang-Undang Lalu lintas dan angkutan jalan telah diterapkan sampai dengan saat ini tapi tidak dapat dipungkiri bahwa tingkat pelanggaran masih tetap terjadi. Dengan banyaknya kasus pelanggaran di jalan raya setidaknya itu bisa menggambarkan cerminan masyarakat bahwa betapa minimnya kesadaran hukum bagi pengendara roda dua (sepeda motor) dan roda empat (mobil). Karena masih banyak orang-orang mengemudi tidak tertib dan taat pada rambu-rambu lalu lintas.Penindakan teguran hanya diberikan kepada pelanggar yang tidak terlalu fatal seperti anak sekolah yang mengendarai dibawah umur yang melakukan pelanggaran (Apriyanto, 2019). Adapun penindakan dengan pemberian surat teguran dapat dilihat dalam tabel berikut :

Tabel 2. Jumlah Penindakan Dengan Pemberian Teguran Pada Tahun 2018-2019

\begin{tabular}{cccc}
\hline No & Tahun & Teguran & Tilang \\
\hline 1 & 2018 & 416 & 3000 \\
2 & 2019 & 500 & 2850 \\
\hline
\end{tabular}

Data: Polres Indragiri Hilir

Undang-Undang Nomor 22 Tahun 2009 pasal 265 ayat 1 butir a berbunyi: pemeriksaan kendaraan bermotor dijalan yang meliputi: pemeriksaan Surat Izin Mengemudi, surat tanda nomor kendaraan bermotor, surat tanda coba kendaraan bermotor, tanda nomor kendaraan bermotor, atau tanda coba kendaraan bermotor. Setiap pengendara sepeda motor yang ke dupannya melanggar lalu lintas maka akan ditindaki dengan tilang. Hal ini dapat kita lihat apabila ada operasi yang dilakukan oleh 
polisi lalu lintas, baik itu mengenai perlengkapan kendaraan, surat-surat maupun marka atau rambu. Seperti penggunaan kenalpot yang nyaring atau tidak sesuai dengan standar sepeda motor tersebut. Pasal 265 ayat 1 butir c berupa pemeriksaan terhadap fisik kendaraan bermotor.

Masalah penetapan sanksi dalam hukum pidana merupakan suatu rangkaian kebijakan yang berada dalam suatu sistem. Sebagai suatu sistem, tidaklah dapat dikatakan bahwa masing-masing tahap pemberian pidana dapat berdiri sendiri, akan tetapi saling terkait bahkan tidak dapat dipisahkan sama sekali (Poncowati et al., 2020). Jadi, bila dihubungkan dengan keseluruhan sistem pemidanaan, penetapan sanksi yang pada hakikatnya merupakan kewenangan beberapa instansi, maka dapat dianalogkan bahwa jatuhnya tahap pemberian sanksi itu harus tertib seperti air pegunungan yang mengalir tertib dan indah meskipun dapat getaran-getaran. Dalam konteks penerapan sanksi, "getaran-getaran" di sini sebagai tamsil tentang kemungkinan terjadinya apa yang disebut dengan disparitas pidana (Disparity of Sentencing).

Implementasi dari Undang-Undang nomor 22 Tahun 2009 Tentang Lalu Lintas dan Angkutan Jalan Raya bukanlah merupakan sesuatu yang mudah dilaksanakan, baik oleh pihak penegak Undang-Undang maupun oleh pihak masyarakat umum. Hal ini disebabkan oleh beberapa hal. Selain faktor karena Undang-Undang ini kurang sosialisasinya di tengah-tengah masyarakat umum sehingga terjadi sikap acuh tak acuh terhadap Undang-Undang No 22 Tahun 2009 ini, juga oleh karena faktor budaya masyarakat serta sarana dan prasarana lalu lintas yang kurang memadai berupa ramburambu dan tempat-tempat pemberhentian.

Selanjutnya, lalu lintas merupakan salah satu sarana komunikasi masyarakat yang memegang peranan vital dalam memperlancar pembangunan yang kita laksanakan. Masalah lalu lintas merupakan salah satu masalah yang berskala nasional yang berkembang seirama dengan perkembangan masyarakat. Kenyataan yang sering di temui sehari-hari adalah masih banyak pengemudi yang belum siap mental, terutamapengemudi angkutan umum dan masyarakat itu sendiri. Mereka saling mendahului tanpa memperdulikan keselamatan dirinya sendiri dan orang lain. Beberapa kecelakaan lalu lintas yang terjadi, sebenarnya dapat dihindari bila diantara pengguna jalan bisa berprilaku disiplin, sopan dan saling menghormati antara satu sama lain

\section{Hubungan Penyuluhan hukum dengan Kesadaran hukum dan Budaya hukum}

Ketentuan yuridis tentang penyuluhan hukum diatur dalam Peraturan Menteri Hukum dan HAM RI Nomor : M-01.PR.08.10 Tahun 2007 tentang Perubahan atas Peraturan Menteri Hukum dan Hak Asasi Manusia RI Nomor : M01.PR.08.10 Tahun 2006 tentang Pola Penyuluhan Hukum. Latar belakang keluarnya peraturan menteri tersebut adalah dalam rangka mengembangkan budaya hukum di semua lapisan masyarakat agar dapat tercipta kesadaran dan kepatuhan hukum demi tegaknya supremasi hukum di Negara Kesatuan Republik Indonesia, perlu dilakukan penyuluhan hukum secara nasional dan agar pelaksanaan penyuluhan hukum secara nasional dapat berjalan secara tertib, terarah, dan terpadu, perlu didasarkan pada pola penyuluhan hukum. Penyuluhan hukum adalah salah satu kegiatan penyebarluasan 
informasi dan pemahaman terhadap norma hukum dan peraturan perundang-undangan yang berlaku guna mewujudkan dan mengembangkan kesadaran hukum masyarakat sehingga tercipta budaya hukum dalam bentuk tertib dan taat atau patuh terhadap norma hukum dan peraturan perundang-undangan yang berlaku demi tegaknya supremasi hukum.

Kesadaran hukum masyarakat adalah nilai yang hidup dalam masyarakat dalam bentuk pemahaman dan ketaatan atau kepatuhan masyarakat terhadap norma hukum dan peraturan perundang-undangan yang berlaku. Kesadaran hukum adalah konsepsi abstrak dalam diri manusia tentang keserasian antara ketertiban dan ketentraman atau yang sepantasnya. Dengan demikian, Kesadaran hukum masyarakat merupakan output dari proses kegiatan penyuluhan hukum yang ditandai dengan adanya rasa untuk menghargai hukum, melalui praktik di lapangan, hanya cara atau teknik penyuluhan hukum yang bersifat komunikatif dan mampu menyentuh hati nurani masyarakat agar menghargai hukum, yang dapat berjalan efektif untuk menimbulkan kesadaran hukum masyarakat.

Pilihan orang dalam berperilaku dan bersikap tindak sesuai dengan yang dikehendaki hukum sangat dipengaruhi oleh moral dan karakter masyarakat, dikarenakan hukum tidak pernah lepas dari lingkungan sosialnya. Penyuluhan Hukum diselenggarakan dengan tujuan mewujudkan kesadaran hukum masyarakat yang lebih baik sehingga setiap anggota masyarakat menyadari dan menghayati hak dan kewajibannya sebagai warga negara dan mewujudkan budaya hukum dalam sikap dan perilaku yang sadar, patuh, dan taat terhadap hukum serta menghormati hak asasi manusia. Lawrence M. Friedman mengatakan bahwa sistem hukum, ada beberapa komponen unsur hukum, yaitu 1) Sistem hukum mempunyai struktur. Sistem hukum terus berubah, namun bagian-bagian sistem itu berubah dalam kecepatan yang berbeda, dan setiap bagian berubah tidak secepat bagian tertentu lainnya; 2) Sistem hukum mempunyai substansi, yaitu berupa aturan, norma, dan pola perilaku nyata manusia yang berada dalam sistem itu; 3) Sistem hukum mempunyai komponen budaya hukum, yaitu sikap manusia terhadap hukum dan sistem hukum itu sendiri,seperti kepercayaan, nilai, pemikiran serta harapannya

\section{SIMPULAN}

Peranan pihak Akademisi dan kepolisian satuan lalu lintas dalam menangani tingginya tingkat pelanggaran lalu lintas di wilayah hukum Polisi Resort Indragiri Hilir, ada beberapa peranan yang dilakukan. Pertama, peranan bidang preventif, seperti melakukan melakukan sosialisasi dan penerangan tentang rambu-rambu lalu lintas ke sekolah-sekolah dengan maksud memberikan penerangan tentang pentingnya mematuhi rambu-rambu lalu lintas, dan menerangkan apa resiko yang akan terjadi jika melanggar rambu-rambu lalu lintas, serta memberikan peringatan-peringatan kepada masyarakat umum tentang pentingnya mematuhi rambu-rambu lalu lintas, seperti memasang spanduk-spanduk dan baliho-baliho yang berhubungan dengan lalu lintas dan menghimbau masyarakat melalui media elektronik yaitu radio.

Kedua, peranan bidang represif, yaitu melakukan penindakan dengan pemberian surat teguran, Penindakan dengan surat teguran hanya diberikan kepada pelanggar yang tidak terlalu fatal seperti anak sekolah yang mengendarai di bawah umur yang 
melakukan pelanggaran. Penindakan dengan pemberian surat tilang, Setiap pengendara sepeda motor yang ke dapan melanggar lalu lintas maka akan ditindaki dengan tilang.

\section{DAFTAR PUSTAKA}

Apriyanto, M. (2019). Pelatihan dan pendampingan pengolahan komoditas kelapa. Jurnal Pengabdian Dan Pemberdayaan Masyarakat, 3(2), 179-183.

Apriyanto, M., Fikri, K. N. S., Siregar, V. A., Jamri, \& Azhar, A. (2020). Penyuluhan tentang peremajaan kelapa sawit dan legalitas lahan di Kecamatan Kempas Kabupaten Indragiri Hilir. ARBITRASE: Journal of Economics and Accounting, 1(1), 1-6. https://doi.org/10.31219/osf.io/7j4sy

Azhar, A., \& Arfiani, V. (2020). Study of handling thugs in the territory of Indragiri Hilir Resort Police. Proceedings of the International Conference on Industrial Engineering and Operations Management, 2175-2178. Detroit: IEOM Society Internasional.

Azhar, A., \& Satriawan, K. N. (2020). Study of law number 9 off regarding freedom of speech in publice. International Journal of Scientific and Technology Research, 9(1), 4002-4006. https://doi.org/10.31219/osf.io/ptqus

Badrunsyah, \& Cahyono, S. (2019). Penyuluhan tentang manajemen keuangan keluarga di RW 06 Kelurahan Cipayung Jakarta Timur. Jurnal Pelayanan Dan Pengabdian Masyarakat, 3(1), 1-9. Retrieved from http://ejournal.urindo.ac.id/index.php/PAMAS.

Fikri, K. N. S., \& Azhar, A. (2020). Implementation of discipline policy for civil servants in Indragiri Hilir Regency post covid pandemic 19. Proceedings of the International Conference on Industrial Engineering and Operations Management, 2188-2191. Detroit: IEOM Society Internasional.

Muharlisiani, L. T., Noerhartati, E., Karwanto, K., Chamidah, D., Wisnujati, N. S., Soewardini, H. M. D., ... Umanailo, M. C. B. (2019). Public relations management through management by objective. International Journal of Scientific and Technology Research, 8(10), 1993-1997. https://doi.org/10.31219/osf.io/ayxrf

Poncowati, S. M., Firdianti, N. C., Hermawan, A. P., Wahyuningtyas, N., Rerung, F. T., Pramaisvara, H., \& Ardina, A. D. (2020). Penganggaran untuk pengendalian organisasi di BUMDes Rukun Makmur. Jurnal Magistrorum Et Scholarium, 01(1), 32-44. 